\title{
Communication
}

\section{Kinetics of inactivation of glutamate decarboxylase by cysteine-specific reagents}

\author{
Sara J. McCormick and Godfrey Tunnicliff $\Omega$
}

Department of Biochem istryand M olecular B i ol ogy, I n di ana U ni ver sitySchool of M ed icine, 8600 Uni ver sity B ou levard, E vans ville, IN 47712, U.S.A.

Received: 30 November, 2000; revised 29 J anuary, 2001; accepted: 15 May, 2001

Key words: in acti va tion, glu ta mate decar box yl ase, cysteinyl resi dues, sulfhydryl groups, mer cu ric chlo ride, p-chloromercuribenzoate, DTNB, Esch erichia coli

Mer cu ric chloride, $p$-chloromercuribenzoate and 5,5'-dithiobis(2-nitrobenzoic acid) irreversibly in hib ited the ac tiv ity of E sch erichia coli gluta matedecar boxylase. Their sec ond or der rate con stants for in ac ti va tion are $0.463 \mu \mathrm{M}^{-1} \mathrm{~min}^{-1}, 0.034 \mu \mathrm{M}^{-1} \mathrm{~min}^{-1}$, $0.018 \mu \mathrm{M}^{-1} \mathrm{~min}^{-1}$, respectively. The characteristics of the inhibition by the three thiol-group re agents sup ports the idea that cysteinyl res i dues at the bind ing sites for the co fac tor and/or the sub strate are im por tant for en zyme ac tiv ity in $E$. coli.

In the vertebrate central nervous system $\gamma$-aminobutyric acid (GABA) is considered as themajor in hibi tory chemi cal transmitter [1]. This amino acid is synthesized from L-glutamic acid by the action of L-glutamate decarboxylase (GAD; EC 4.1.1.15) which requires pyridoxal 5'-phosphate (PLP) as cofactor [2]. GABA is also synthesized by plants and mi cro or gan isms, al though in thoseor ganisms not pos sessing nervetis sue, thefunction of this amino acid is not quite clear. Ev i dence for Escherichia coli suggests that GAD can protect the pathogen from acid shock in the stomach [3].

A con sid er ablenum ber of in hibitors of mam malian GAD have been identified, including residue-specific reagents which have given clues about those amino ac ids that might bevital for cat a lytic ac tiv ity [4, 5]. F rom such studies evidence has emerged that sulfhydryl groups of cer tain cysteinyl res i dues areim portant for enzyme activity $[6,7]$.

${ }^{\Omega}$ Au thor for correspondence: phone: (812) 464 1833; fax: (812) 465 1184; e-mail: gtunnic@iupui.edu Abbreviations: DTNB , 5,5'-dithiobis(2-nitrobenzoate); GABA, $\gamma$-aminobutyric acid; GAD, glu ta mate de car boxylase; $\mathrm{PCMB}, \mathrm{p}$-chloromercuribenzoate; NEM, $N$ ethylmaleimide; PLP, pyridoxal 5'-phosphate. 
Glutamate decarboxylase from microorganisms has not been stud ied as thor oughly as the mammalian enzyme. It is known, however, that the enzyme from Streptococcus pneu moniae has a mo lecular mass of $54400 \mathrm{Da}$ and exhibits $28 \%$ homology with $\mathrm{GAD}_{65}$ from brain [8]. GAD from E. coli and Clostridium perfringens con sists of sixiden ti cal sub units each with a mo lec u lar mass of about $50000 \mathrm{Da}$ [9, 10]. As in eukaryotes, the prokaryotic en zyme (E. coli) is encoded by two distinct genes whose sequences have been determined [11-13]. The protein products differ in only five amino-acid residues and their functional properties are iden ti cal. The en zyme from E. coli shows different physical and catalytic properties from the mammalian protein but does ex hibit some sim i lar i ties to the brain enzyme as far as its in hi bi tion by sub stratean a logues and divalent cations, although quantitative dif fer ences do ex ist [14].

Compounds which react specifically with someamino acids can beuseful for deter mi na tion of the cat alyticactivity of en zymes. Loss of en zymeac tiv ity and pro tection against this loss by sub strates or co factors on ex po sure of enzyme to these reagents provides evidence that the respective amino acids are essential for biological activity. There is already some ev i dencethat sulfhydryl groups areim por tant for bac te rial GAD activ ity [15-17]. W ith this in mind, the pres ent in ves ti ga tion was un dertaken to determine the kinetic mechanismof theaction of sev eral cysteine-specific reagents on GAD from $E$. coli.

\section{MATERIALS AND METHODS}

Enzyme and chemicals. L-Glutamate decarboxylase (40 units/mg protein) from E. coli, L-glutamic acid, pyridoxal 5'-phosphate, $\mathrm{N}$-ethylmaleimide, $\mathrm{p}$-chloromercuribenzoate, chloroacetamide, iodoacetate, 5,5'dithiobis(2-nitrobenzoic acid) and mercuric chlo ride were ob tained from Sigma Chem i cal Co. L $\left[1-{ }^{14} \mathrm{C}\right]$ Glutamate $(54 \mathrm{mCi} / \mathrm{mmol})$ was purchased from Research Products International.

Glutamate decarboxylase assay. The activ ity of theen zyme was mea sured by in cu bat ing 0.02 units at $37^{\circ} \mathrm{C}$ in the pres ence of $1 \mathrm{ml}$ of $50 \mathrm{mM}$ sodium acetate/ acetic acid buffer, $\mathrm{pH} 4.6$, containing $0.4 \mathrm{mM}\left[{ }^{14} \mathrm{C}\right]$ glutamate, $0.05 \mathrm{mM}$ PLP and $120 \mathrm{mM} \mathrm{NaCl}$. The evolved radioactive $\mathrm{CO}_{2}$ was trapped in $0.1 \mathrm{M}$ potassium hy droxide. Thereaction waster mi nated by the addition of $0.1 \mathrm{ml}$ of $0.8 \mathrm{~N} \mathrm{H}_{2} \mathrm{SO}_{4}$ and thein cu bation con tin ued for a fur ther $30 \mathrm{~min}$ to en surethe release of all car bon di ox ide. Ra dio ac tiv ity was counted in a Beckman LS100 liquid-scintillation spectrometer. Flasks containing no en zyme were used as blanks.

Inactivation ofgluta matedecar boxylase. For thein acti vation exper i ments, en zymewas in cu bated at room tem per a turein so dium ace tate/acetic acid buffer, pH 4.6, with several different concentrations of inhibitor, with or with out glu ta mate or PLP, for var i ous lengths of time. In the course of the in cu bation, $20 \mu \mathrm{l}$ aliquots of the mixture were successfully removed and added to $1.98 \mathrm{ml}$ of ac e tate buffer containing $0.4 \mathrm{mM}$ radioactive glutamate, $0.05 \mathrm{mM}$ PLP and $120 \mathrm{mM} \mathrm{NaCl}$. The activity of the enzyme was then measured by incubation at $37^{\circ} \mathrm{C}$ as described above.

\section{RESULTS}

The enzyme activity was assayed as described in Methods at $\mathrm{pH} 4.6$ in the presence of DTNB, chloroacetamide, iodoacetate, NEM, PCMB or mercuric chloride. Only mercuric chloride, pCMB and DTNB inhibited enzyme activity (Table 1 ). In each case the inhibition was ir revers iblesince, if en zyme beforetheas say was di luted 50 -fold with buffer, the de gree of in hi bi tion was the sameas if each in hibi tor had been present during the incubation.

Under the conditions of the inactivation experiments, the rate of activity loss exhibited pseudo-first-order kinetics and was proportional to inhibitor concentration (Fig. 1). At 
the highest inhibitor concentration $(3 \mu \mathrm{M})$, however, pseudo-first-order kinetics was observed for the first 15 min only.

The observed rates of inactivation ( $k_{o b s}$ ), which are the pseudo-first-order rate constants, can be related to thein hibi tor con centration [I] by the equation:

$k_{\text {obs }}=k_{2}[\mathrm{I}]^{\mathrm{n}}$

where $n$ is the re ac tion or der andk 2 is the second-order rate constant [18]. Thereforethese results are consistent with the inactivation process following second-order kinetics as a bimolecular reaction:

$$
\mathrm{E}+\mathrm{I} \stackrel{\mathrm{k}_{2}}{\longrightarrow} \mathrm{E}-\mathrm{I}
$$

where $E$ is enzyme, I is inhibitor, and $E-I$ is the stable enzyme-inhibitor complex. The simple bimolecular rate constant $\left(k_{2}\right)$ for $\mathrm{HgCl}_{2}$ was calculated as $0.463 \mu \mathrm{M}^{-1} \mathrm{~min}^{-1}$. This was done by mul ti ply ing theslope of the lines by 2.303 and dividing by the inhibitor concentration. Further experiments were done un der iden ti cal con di tions and are summa rized in the in set to Fig. 1. Thelack of an inter cept on they axis sup ports the idea of a simplebi molecular reaction dur ing which no mea surable transient inhibitor-enzyme complex was formed; i.e., the mercuric chloride was not acting as an af fin ityla bel.

A similar pattern of inactivation was observed when either PCMB or DTNB was the inhibitor (Figs. 2 and 3). In both cases inactivation fol lowed pseudo-first-order ki net ics, at though at the highest DTNB concentration $(100 \mu \mathrm{M})$, pseudo-first-order ki net ics was seen for the first 12 min only. As in the case with mer cu ric chlo ride, the in crease in the rate of in acti vation was propor tional to thein hibitor con cen tration (Figs. 2 and 3 , in set), in di cating that no transient enzyme-inhibitor complex was formed. The second-order rate constant was cal cu lated as $0.034 \mu \mathrm{M}^{-1} \mathrm{~min}^{-1}$ and 0.018

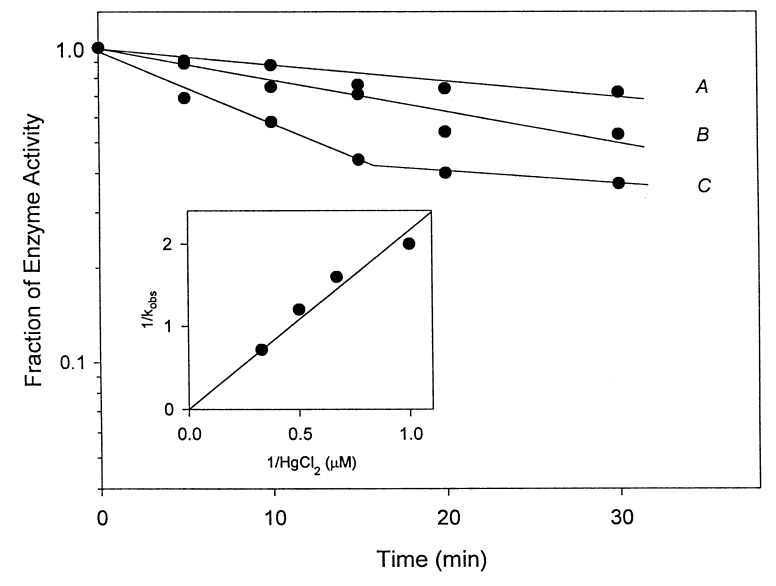

Figure 1. Remaining enzyme activity as a func tion of $\mathrm{HgCl}_{2}$ con cen tra tion and time of exposure.

$\mathrm{A}=1.5 \mu \mathrm{M} \mathrm{HgCl} 2$ and $1 \mathrm{mM}$ pyridoxal 5' -phos phate; $\mathrm{B}$ $=1.5 \mu \mathrm{M} \mathrm{HgCl}_{2} ; \mathrm{C}=3.0 \mu \mathrm{M} \mathrm{HgCl}_{2}$. In each case the rate of in activation $\left(\mathrm{k}_{\mathrm{obs}}\right)$ was obtained by multiplying the slope of the line by 2.303. Each point is the mean of four determinations and the coefficient of variation was never greater than $10 \%$. The enzyme activity at $100 \%=16.5 \mu \mathrm{mol} / \mathrm{min}$ per $\mathrm{mg}$ protein. Thein set shows there cip ro cal of $k_{\text {obs }}$ plot ted against the recip ro cal of inhibitor concentration. For the sake of clarity, the data for additional two points in the inset are not shown in the main graph.

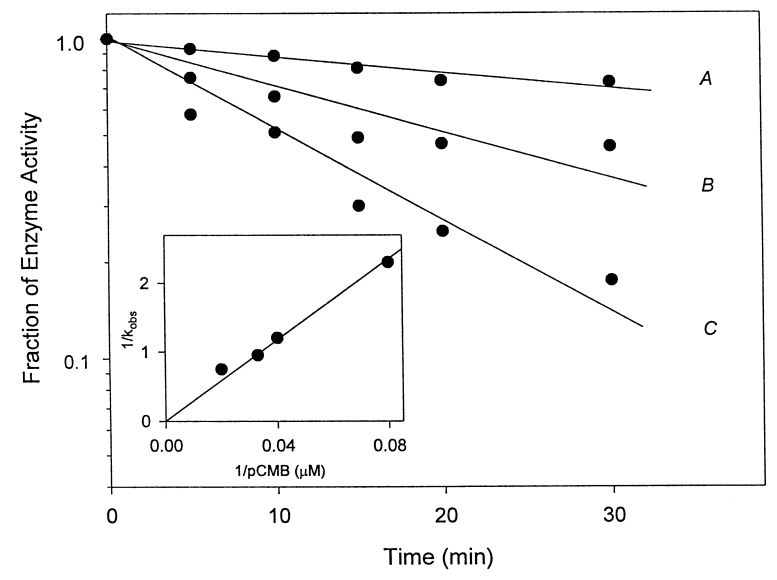

Figure 2. Remaining enzyme activity as a func tion of PCMB con cen tra tion and time of exposure.

$\mathrm{A}=25 \mu \mathrm{M}$ pCMB and $1 \mathrm{mM} \mathrm{PLP} ; \mathrm{B}=25 \mu \mathrm{M} \mathrm{pCMB} ; \mathrm{C}=$ $50 \mu \mathrm{M} \mathrm{pCMB}$. For other de tails see leg end to Fig. 1. 
$\mu \mathrm{M}^{-1} \min ^{-1}$ for $\mathrm{pCMB}$ and DTNB, respectively.

If PLP was present during the exposure of enzyme to either of the three inhibitors, the rate of inactivation was reduced in each case (Figs. 1, 2 and 3). The pro tec tion was con centra tion de pend ent, al though only one con cen-

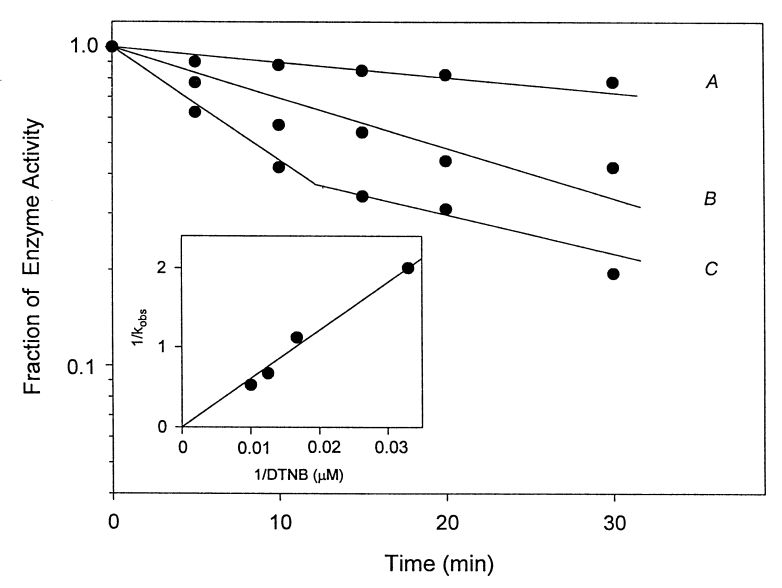

Figure 3. Remaining enzyme activity as a func tion of DTNB con cen tra tion and time of exposure.

$\mathrm{A}=60 \mu \mathrm{M}$ DTNB and $1 \mathrm{mM}$ pyridoxal 5 -phos phate; $\mathrm{B}=$ $60 \mu \mathrm{M}$ DTNB and $10 \mathrm{mM}$ glu ta mate; $\mathrm{C}=60 \mu \mathrm{M}$ DTNB; $\mathrm{D}=100 \mu \mathrm{M}$ DTNB.

tration is illustrated in the graphs. On the other hand, the presence of $10 \mathrm{mM}$ glutamic iodoacetate, NEM or chloroacetamide was monitored. The enzyme was assayed at $\mathrm{pH}$ $4.0,5.0,6.0,7.0$ or 8.0 in the ab sence or presence of $100 \mu \mathrm{M}$ of each com pound. In the absence of inhibitor, the enzyme activity reached a peak between $\mathrm{pH} 4.0$ and 5.0. lodoacetate had no marked ef fects on en zyme activity but both NEM and chloroacetamide showed a significant inhibitory effect at $\mathrm{pH}$ 6.0 and higher pH values (not shown).

\section{DISCUSSION}

Glutamate decarboxylase from E. coli was exposed to six different sulfhydryl-group reagents at $\mathrm{pH} 4.6$, but the ac tiv ity was in hibited by $\mathrm{HgCl}_{2}$, pCMB and DTNB only. In each case, the inhibition was irreversible. The three inhibitors behaved similarly towards the en zyme. Each pro duced an in acti va tion that for lowed pseudo-first-order ki net ics and was linear with inhibitor concentration. Consequently, there was no evidence for the compounds producing readily reversible enzyme-inhibitor complexes and therefore no inhibitor binding constant could be calcur lated. The other three sulfhydryl-selective reagents - iodoacetate, NEM and chloroace-

Ta ble 1. E f fects of sulfhydryl-group re agents on E . coli glu ta mate decar box yl ase ac tiv ity at pH 4.6.

\begin{tabular}{lc}
\hline Reagent & Percentinhibition \\
\hline $\mathrm{HgCl}_{2}$ & $80.1 \pm 11.0$ \\
$p$-Chloromercuribenzoate & $68.5 \pm 7.7$ \\
$5,5^{\prime}$-Dithiobis(2-nitrobenzoate) & $50.3 \pm 11.1$ \\
lodoacetate & $4.6 \pm 3.3$ \\
$\mathrm{~N}$-Ethylmaleimide & $0.9 \pm 6.3$ \\
Chloroacetamide & $-0.3 \pm 0.4$ \\
\hline
\end{tabular}

En zyme as sayed as de scribed in the Ma te rials and M ethods. $\mathrm{HgCl}_{2}$ con cen tra tion $=1 \mu \mathrm{M}$, all other com pounds $=100 \mu \mathrm{M}$. Values rep resent mean ( \pm S.D.) of 10 deter mi na tions.

acid reduced the rate of inactivation only by DTNB but not by the other two compounds. In one experiment the effects of increasing $\mathrm{pH}$ on the potential inhibitory action of tamide-had no ap precia ble ef fect on en zyme activity. This might be explained by the relatively acidic con di tions of thereaction. There ac tivity of these reagents is $\mathrm{pH}$ depend ent, the 
optimum range being $\mathrm{pH}$ 6-8. Indeed, when NEM or chloroacetamide were ex posed to the enzyme at pH 6.0 or higher, an inhibition of enzyme activity was observed (not shown). This is in contrast to both mercuric chloride and $\mathrm{PCMB}$ whose reaction with proteins is the highest at about pH 5 [19].

The co factor PLP was able to pro tect against the inactivation by the two mercurial compounds, as well as by DTNB. The substrate, however, did not protect against the inhibition by the mer cu ri als but did pro tect against in hi bition by DTNB. Con sequently, thesedata provide evi dence that es sen tial cysteinyl res - dues reside at or near the cofactor binding site. In fact, previous studies had indicated that $\mathrm{PCMB}$ and mercuric chloride could adversely affect the activity of this enzyme although no ki netic data were pro vided [14, 16]. Actually, both Strausbauch \& Fischer [9] and Fonda [15] have used DTNB to estimate the number of cysteinyl residues pres ent in each sub unit of theen zyme. The es ti mates wereeither 9 or 10 cysteines per subunit. Further, bromopyruvate was shown to inactivate E. coli GAD by alkylating one essential sulfhydryl group on each sub unit [15]. In this regard, the bacterial enzyme resembles GAD from mam ma lian brain since thelat ter is sus cep ti bleto in hi bi tion by reagents which react with thiol groups $[6,7,20,21]$.

In sum mary, we have shown that GAD from E. coli was irreversibly in hib ited by thethree sulfhydryl-group reagents, mer cu ricchlo ride, PCMB and DTNB, with mercuric chloride being by far the most ef fective. Sincepyridoxal 5 '-phos phate pro tected the en zyme against inhibition by all three compounds, it might be con cluded that cysteinyl res i dueis im por tant for cofactor function. Glutamate offered protection only against the ef fects of DTNB, suggesting cysteinyl residues also play a role in glu ta matebind ing to theen zyme. How ever, it is not clear why it did not pro tect against the action of $\mathrm{HgCl}_{2}$ and $\mathrm{pCMB}$.
We are grate ful to Dr. T.T. Ngo for crit i cally reading the manuscript and offering helpful suggestions.

\section{REFERE N CES}

1. Krnjevic, K. (1991) in GABA Mechanisms in Epilepsy (Tunnicliff, G. \& Raess, B.U., eds.) pp. 47-87, Wiley-Liss, New York.

2. Tunnicliff, G \& Ngo, T.T. (1986) Neurochem. Int. 8, 287- 297.

3. De Biase, D., Tramonti, A., Bossa, F. \& Visca, P. (1999) M ol. Microbiol. 32, 1198- 1211.

4. Tunnicliff, G. (1990) Int. J. Biochem. 22, 1235- 1241.

5. Tunnicliff, G. (1991) in GABA M ech a nismsin Epilepsy (Tunnicliff, G. \& Raess, B.U., eds.) pp. 189-204, Wiley-Liss, New York.

6. Rob erts, E. \& Simonsen, D.G. (1963)Biochem. Pharmacol. 12, 113- 134.

7. Wu, J.Y. \& Rob erts, E. (1974) J. Neurochem. 23, 759- 767.

8. García, E. \& López, R. (1995)FE MS Microbiol. Lett. 33, 113- 118.

9. Strausbauch, P.H. \& Fischer, EH. (1970) Biochemistry 9, 226- 233.

10.Cozzani, I. \& Bagnoli, G. (1973) Ital. J. Biochem. 22, 36- 45.

11. Maras, B., Swee ney, G., Barra, D., Bossa, F. \& J ohn, R.A. (1992) Eur. J. Biochem. 204, 93- 98.

12.Smith, D.K., Kassam, T., Singh, B. \& Elliott, J .F. (1992) J . Bacteriol. 174, 5820-5826.

13. De Biase, D., Tramonti, A., John, R.A. \& Bossa, F. (1996) Protein Expression Purifica tion 8, 430- 438.

14.Youngs, T.L. \& Tunnicliff, G. (1991) Biochem. Int. 23, 915-922. 
15. Fonda, M.L. (1976) J. Biol. Chem. 251, 229- 235.

16. Shukuya, R. \& Schwert, G.W. (1960) J . Biol. Chem. 235, 1658-1661.

17. Sukhareva, B.S., Tikhonenko, A.S. \& Darii, E.L. (1995) Mol. Biol. 28, 874- 876.

18. Levy, H.M, Leber, P.D. \& Ryan, E.M. (1963)J . Biol. Chem. 238, 3654- 3659.
19. Means, G.E. \& Feeney, R.E. (1971) Chemical Modification of Proteins. Holden-Day, San Francisco.

20.Tunnicliff, G. \& Wood, J.D. (1973) Comp. Gen. Pharmacol. 4, 101- 105.

21.Tunnicliff, G. \& Ngo, T.T. (1978) Int. J. Biochem. 9, 249- 252. 